J䟢ALL JOALL (JOURNAL OF APPLIEI) LINGUIS'IICS ANI) LIT'ERA'TURE)

Vol. 7 No. 1, February 2022

ISSN (print): 2502-7816; ISSN (online): 2503-524X

Available online at https:/ / ejournal.unib.ac.id/index.php/joall/article/view/18855

http://doi.org/10.33369/joall.v7i1.18855

\title{
Teachers' perceptions of challenges in online learning: Voices from secondary EFL teachers
}

\author{
${ }^{1}$ Dwi Bayu Saputra ${ }^{D},{ }^{2}$ Honesty Yonanda Ayudhia ${ }^{D},{ }^{3}$ Reci Muswari ${ }^{(D)}$ \\ 1,2English Education, Universitas Pendidikan Indonesia, INDONESIA \\ ${ }^{1}$ Jl. Dr. Setiabudi No.229, Isola, Bandung, West Java \\ ${ }_{3}^{3}$ SMA Negeri 10, Kota Bengkulu, INDONESIA \\ ${ }^{3}$ Jl. Padang Cengkeh, Suka Rami, Bengkulu
}

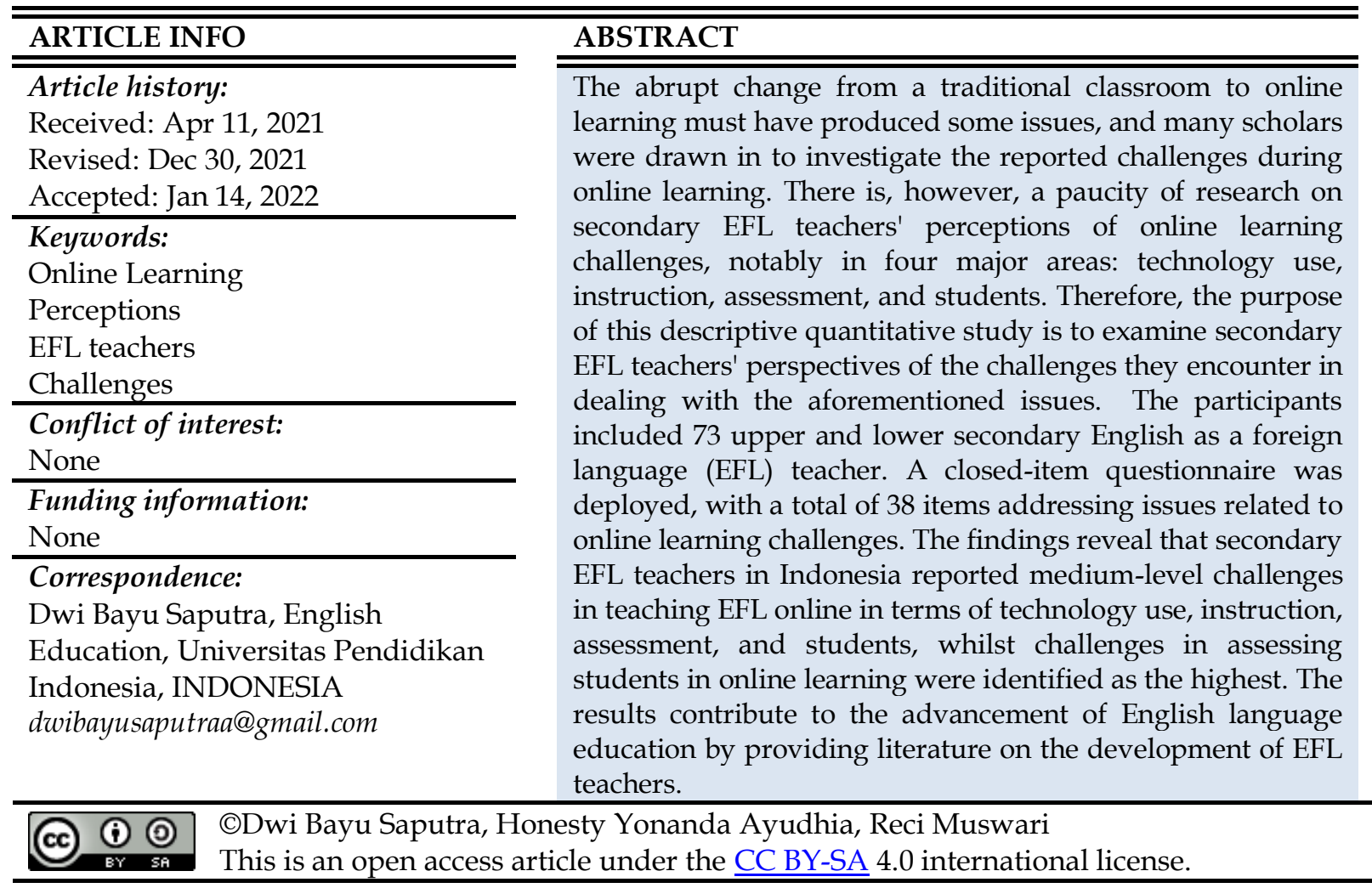

How to cite (APA Style):

Saputra, D.B., Ayudhia, H.Y., Muswari, R. (2022). Teachers' perceptions of challenges in online learning: Voices from secondary EFL teachers. JOALL (Journal of Applied Linguistics and Literature), 7(1), 104-118 https:// doi.org/10.33369/joall.v7i1.18855

It has been almost two years since the World Health Organization (WHO) declared a global pandemic due to the Corona Virus on March 11, 2020. Government and non-governmental institutions have implemented strict social distancing measures and a lockdown strategy in reaction to the global pandemic. This outbreak had a devastating impact on educational institutions all across the countries, including Indonesia. The rapid spread of Covid-19 
Teachers' perceptions of challenges in online learning: Voices from secondary...

constituted a huge threat to the educational landscape, forcing educational institutions to close and seek other teaching and learning methods (Mseleku, 2020). According to Jena (2020) nearly every country in the world has temporarily closed schools and higher education institutions to tackle the rising prevalence of COVID-19 in their nation. In Indonesia, Schools and Higher Education Institutions (HEIs) have been temporarily shuttered starting March 14th, 2020 (Mailizar et al., 2020).

To keep running the teaching and learning process, the Indonesian government took the initiative to conduct distance learning as one of the most possible options left. Consequently, teachers must be able to quickly adjust their styles, strategies, or methods of teaching so that the learning and teaching process is not hampered and students still get their right to acquire knowledge. Also, shifting from traditional to online learning during this outbreak implies that learning, regardless of the condition, should be fully integrated with Information and Communication Technologies (ICT). However, transitioning from a traditional classroom to cyberspace in such a short period caused significant issues for schools, instructors, and students. Furthermore, having limited or even no experience with ICT will burden both the teachers and the students. Schools that do not have established e-learning materials will face some challenges, particularly when teachers do not know how to use online programs (Zaharah, Kirilova, and Windarti, 2020).

The recent shift to online education as a result of the COVID-19 pandemic revealed numerous flaws in online learning (Gao \& Zhang, 2020). This could be due to the parties involved in education, such as schools, teachers, and students, being perplexed by the abrupt and forced change. Although some teachers and students are familiar with computers or smartphones, fully utilizing ICT for educational purposes requires teachers' expertise, knowledge, and understanding of their students, as well as their subject and content. Therefore, now is the moment to rethink, restructure, and reorganize our educational system in light of the current, unprecedented demand (Mishra, Gupta, and Shree, 2020). Thus, figuring out what prevents teachers from properly implementing online learning is significant.

To date, a number of researchers have begun to look at the obstacles, barriers, and issues that both teachers and students face when dealing with online learning. The majority of studies on the challenges faced by teachers and students in e-learning implementation were conducted at the tertiary level (e.g., Gulnaz et al., 2019; Bao, 2020; Abduh, 2021;Alhuwaydi, 2021;Mishra et al., 2020;Naylor \& Nyanjom, 2021;Nugroho \& Mutiaraningrum, 2020; Hashemi, 2021). Hashemi (2021) conducted a quantitative survey of university lecturers' perspectives of potential and problems in online teaching in Afghanistan at the tertiary level. Another study conducted in India focused on investigating teachers' and students' attitudes 
of online teaching-learning modes, as well as the implementation process of online teaching-learning modes (Mishra, Gupta, and Shree, 2020). In the Indonesian context, Nugroho \& Mutiaraningrum, (2020) conducted a qualitative study on lecturers teaching at the English department and the center for language development investigating EFL teachers' beliefs and practices on digital learning.

However, in comparison to the abundance of literature on the issues faced by university teachers, studies on secondary teachers' perspectives of the challenges in remote learning tend to be scarce. (e.g., Khatoony \& Nezhadmehr, 2020;König et al., 2020;Atmojo \& Nugroho, 2020;Mailizar et al., 2020). König et al., (2020) surveyed 165 early career teachers to investigate the effects of school computer technology, teachers' professional competence, and opportunities for acquiring digital competence to help them grasp teaching online throughout the pandemic. Meanwhile, in the Indonesian context, Atmojo \& Nugroho (2020) conducted a qualitative design study to explore the challenges faced by EFL teachers in online education. Their study was primarily focused on the applications and platforms used by the teachers, how they carry out online EFL learning, and the challenges they encounter, with no consideration for students or assessment areas. Mailizar et al., (2020) did another study that looked into science instructors' difficulties in terms of teacher, school, curriculum, and students. Unfortunately, this study does not look into factors of assessment, which are crucial to look into because they can help with future online learning.

There have been no studies to date that looked into secondary EFL teachers' perceptions of challenges faced in online learning particularly in four key areas: technology use, instruction, assessment, and students. This study aimed to investigate these issues to close the gap. The findings of this study will aid in the development of our understanding of the issues of teaching and learning online in the setting of developing countries at the secondary school level during or after the COVID-19 epidemic. As a result, this research adds to the body of knowledge about online teaching and makes constructive recommendations for the improvement of online teaching techniques. This study attempts to address the following research question to attain those goals "what are secondary EFL teachers 'perceptions of the challenges they faced concerning the use of technology, instruction, assessment, and students?"

\section{METHODS}

\section{Participants}

The present study employed a quantitative design in which the researchers conducted a survey to investigate secondary EFL teachers' perspectives of online learning challenges, focusing on four main areas: technology use, instruction, assessment, and students. Quantitative approaches, according to 
Teachers' perceptions of challenges in online learning: Voices from secondary...

Fraenkel et al (2017), are capable of producing accurate, valid, objective, and generalizable results. Furthermore, questionnaires, which are one of the most extensively used quantitative tools, can be distributed to a significant number of individuals. Generalizations about the entire population can be produced if the researcher gets data from a representative sample of the population (Fraenkel et al, 2017).

In this current research, random sampling was used. The participants included 73 upper and lower secondary English as a Foreign Language (EFL) teacher (17 males and 56 females) from some different regions like Bengkulu, West Sumatra, West Java, and East Nusa Tenggara. They employ Zoom, Google Meet, Google Classroom, and WhatsApp in their classrooms for both synchronous and asynchronous instruction. All respondents were also informed that their identities would be kept confidential. Furthermore, the majority of the participants (72,6 percent) held undergraduate degrees in Language teaching, while the remainder had post-graduate degrees $(27,4$ percent). Moreover, the majority of the participants $(73.9 \%)$ had more than 10 years of teaching experience, and 75.3 percent of the participants taught in senior high schools, with the remaining 24.7 percent teaching in junior high schools. Further details of participants' demographic information are presented in table 1.

Table 1. Demographic Background of Participants

\begin{tabular}{clll}
\hline $\begin{array}{c}\text { Demographic } \\
\text { Background }\end{array}$ & Participants & Percentage \\
\hline Gender & Male & 17 & 23.3 \\
& Female & 56 & 76.7 \\
Level of Education & Undergraduate Degree & 53 & 72.6 \\
& Postgraduate Degree & 20 & 27.4 \\
Teaching Experiences & $0-2$ & 7 & 9.6 \\
& $3-5$ & 3 & 4.1 \\
& $6-10$ & 9 & 12.3 \\
& $11-15$ & 19 & 26 \\
& $>15$ & 35 & 47.9 \\
\hline
\end{tabular}

\section{Instruments}

This study employed a survey-based questionnaire to evaluate secondary EFL teachers' perceptions on online learning issues, concentrating on four major areas: technology use, instruction, assessment, and students. The data was collected through an online questionnaire created using a google form. On October 18, 2021, the questionnaires were sent to respondents via WhatsApp in two ways: one-by-one and in groups. Two weeks is considered as an adequate time frame for respondents to respond to the sent questionnaire. This is due to the fact that, due to their hectic schedules, not all respondents are able to answer to the questionnaire as soon as it is distributed. The 
compatibility with teachers' online work during the pandemic was a critical consideration for employing an online questionnaire. Furthermore, the online questionnaire was relatively easy to administer and access using a variety of devices (Fraenkel et al, 2017).

The questionnaire was adapted from Alhuwaydi (2021), with certain adjustments made to reflect the context of online learning in Indonesia (see appendix). It included 38 items divided into four categories: technology use (10 items), instruction ( 9 items), assessment ( 9 items), and students (10 items). The questionnaire also included a section for personal information, such as gender, school level, and years of teaching. The questionnaire was designed to elicit responses to four study questions about perceptions of teaching secondary EFL classes online and in connection to a teacher's gender. Responses to items were graded on a 5 -point Likert scale $(1=$ strongly disagree, 2 = disagree, 3 = neutral, $4=$ agree, 5 = strongly agree). Some items were inverted to test responders' comprehension.

\section{Data analysis procedures}

SPSS was used to examine the data (Version 26). Using means and standard deviations, the respondents' technology use, instruction, assessment, and students were determined. Internal consistency was measured using Cronbach's alpha, as indicated in Table 2.

\section{Table 2. Internal Consistency of The Questionnaire}

\begin{tabular}{ll}
$\begin{array}{l}\text { Cronbach's } \\
\text { Alpha }\end{array}$ & N of Items \\
\hline 860 & 38 \\
\hline
\end{tabular}

As shown in Table 2, the consistency coefficient for 38 items of the questionnaire reaches 0.860 indicating that the close-ended questionnaire has a high reliability.

\section{FINDINGS}

What are secondary EFL teachers 'perceptions of the challenges they faced concerning the use of technology, instruction, assessment, and students?

To answer Research Question, the means and standard deviations of EFL teachers' questionnaire responses were calculated. The following scale was used to assess the level of difficulty: $1-1.80=$ very low,$>1.80-2.60=$ low, $>2.60-3.40=$ medium, $>3.40-4.20=$ high,$>4.20-5=$ very high. Table 3 shows secondary EFL teachers' perceptions of the challenges of employing technology for online instruction, which were regarded as Medium overall $(\mathrm{M}=2.94)$.

\section{Table 3. Challenges With Using Technology in Online EFL Instruction}


Teachers' perceptions of challenges in online learning: Voices from secondary...

\begin{tabular}{|c|c|c|c|c|}
\hline Statement & $\mathbf{N}$ & Mean & $\begin{array}{l}\text { Standard } \\
\text { Deviation }\end{array}$ & Level \\
\hline Overall & & 2.94 & & Medium \\
\hline $\begin{array}{l}\text { In terms of resources, time, and effort, } \\
\text { integrating technology into EFL online teaching } \\
\text { is costly. }\end{array}$ & 73 & 3.73 & .986 & High \\
\hline $\begin{array}{l}\text { Due to a lack of proper teacher training, } \\
\text { technology integration in EFL online } \\
\text { instruction is ineffective. }\end{array}$ & 73 & 3.27 & 1.044 & Medium \\
\hline $\begin{array}{l}\text { I am skilled at teaching EFL online using } \\
\text { computers. }\end{array}$ & 73 & 2.15 & .952 & Low \\
\hline $\begin{array}{l}\text { I can design EFL lessons with the help of } \\
\text { computers to deliver online lectures. }\end{array}$ & 73 & 2.08 & .878 & Low \\
\hline $\begin{array}{l}\text { To teach EFL online, I have good Internet } \\
\text { connectivity and computers. }\end{array}$ & 73 & 2.32 & 1.028 & Low \\
\hline $\begin{array}{l}\text { It is costly to have a computer and Internet } \\
\text { connectivity to teach EFL online. }\end{array}$ & 73 & 3.58 & 1.025 & High \\
\hline $\begin{array}{l}\text { The EFL learning process would be limited by } \\
\text { the lack of training in the use of online teaching } \\
\text { tools. }\end{array}$ & 73 & 4.10 & .773 & High \\
\hline $\begin{array}{l}\text { In EFL online teaching platforms, poor Internet } \\
\text { and device compatibility, such as computers, } \\
\text { are challenges. }\end{array}$ & 73 & 3.98 & .807 & High \\
\hline $\begin{array}{l}\text { During live online teaching, I can share screens, } \\
\text { applications, and files such as.pdf,.ppt, and.jpg } \\
\text { with my students. }\end{array}$ & 73 & 1.86 & .804 & Low \\
\hline $\begin{array}{l}\text { I can use microphone, camera, chat, } \\
\text { whiteboard, groups, and polls, among other } \\
\text { elements of live teaching. }\end{array}$ & 73 & 2.28 & .889 & Low \\
\hline
\end{tabular}

Table 3 reveals that the primary challenges in employing technology for EFL teachers were a lack of training to use online teaching platforms $(M=4.10$, $\mathrm{SD}=.773)$ and inadequate connection and device compatibility (M=3.98, $\mathrm{SD}=.807)$. Meanwhile, the ability to share screens, apps, and documents, such as.pdf,.ppt, and.jpg, with students during online live teaching ( $M=1.86$, $\mathrm{SD}=.804$ ) and the ability to construct EFL courses using computers to present online lectures $(\mathrm{M}=2.08, \mathrm{SD}=.878)$ were the lowest-rated issues. Table 4 demonstrates that EFL teachers assigned a medium rating to instructional challenges when teaching online.

Table 4. Challenges with Online EFL instruction

\begin{tabular}{lllll}
\hline \multicolumn{1}{c}{ Statement } & $\mathbf{N}$ & Mean & $\begin{array}{c}\text { Standard } \\
\text { Deviation }\end{array}$ & Level \\
\hline Overall & 3.02 & & Medium \\
\hline $\begin{array}{l}\text { My options for instructional resources in EFL } \\
\text { online teaching are limited due to the }\end{array}$ & 2.89 & 1.112 & Medium \\
incorporation of technology.
\end{tabular}




\begin{tabular}{|c|c|c|c|c|}
\hline Statement & $\mathbf{N}$ & Mean & $\begin{array}{c}\text { Standard } \\
\text { Deviation }\end{array}$ & Level \\
\hline $\begin{array}{l}\text { Incorporating technology into EFL online } \\
\text { teaching necessitates more time to plan } \\
\text { learning activities. }\end{array}$ & 73 & 3.64 & 1.005 & High \\
\hline $\begin{array}{l}\text { A direct teaching method is mainly used in EFL } \\
\text { online teaching platforms. }\end{array}$ & 73 & 3.36 & .905 & Medium \\
\hline $\begin{array}{l}\text { Working in groups or in peers with students in } \\
\text { EFL online teaching platforms is pretty hard. }\end{array}$ & 73 & 3.41 & 1.115 & High \\
\hline $\begin{array}{l}\text { In EFL online teaching platforms, students may } \\
\text { find it difficult to understand verbal } \\
\text { instructions. }\end{array}$ & 73 & 3.42 & 1.141 & High \\
\hline $\begin{array}{l}\text { Due to a lack of technological expertise, I am } \\
\text { finding it challenging to transition from } \\
\text { traditional EFL teaching to online teaching. }\end{array}$ & 73 & 3.12 & 1.079 & Medium \\
\hline $\begin{array}{l}\text { Some teaching strategies, such as grammar } \\
\text { translation, communicative, or audio-lingual } \\
\text { approaches, are challenging to implement } \\
\text { when teaching EFL online. }\end{array}$ & 73 & 3.21 & 1.133 & Medium \\
\hline $\begin{array}{l}\text { I can deliver learning activities using } \\
\text { technology and the Internet, such as email, } \\
\text { PowerPoint presentations, and the Internet. }\end{array}$ & 73 & 1.86 & .854 & Low \\
\hline $\begin{array}{l}\text { I am capable at designing digital learning } \\
\text { activities for my students. }\end{array}$ & 73 & 2.30 & .952 & Low \\
\hline
\end{tabular}

Table 4 shows that EFL teachers' highest-rated challenges in instruction were the need for more time to organize learning activities than in a face-to-face classroom $(\mathrm{M}=3.64, \mathrm{SD}=1.005)$ and the inability of students to grasp verbal instructions to learn lessons in EFL online teaching platforms came in second place $(\mathrm{M}=3.42, \mathrm{SD}=1.141)$. In the meantime, the lowest-rated challenges were the ability to deliver learning activities through technology and the Internet, such as email, PowerPoint presentations, and the Internet and the second lowest was the capacity to construct technology-enhanced learning activities for the students $(\mathrm{M}=2.30, \mathrm{SD}=.952)$. Table 5 demonstrates that assessment challenges when teaching online were regarded as medium by secondary EFL teachers.

Table 5. Challenges with Assessment in Online EFL Instruction

\begin{tabular}{|c|c|c|c|c|}
\hline Statement & $\mathbf{N}$ & Mean & $\begin{array}{c}\text { Standard } \\
\text { Deviation }\end{array}$ & Level \\
\hline Overall & & 3.14 & & Medium \\
\hline $\begin{array}{l}\text { The integrating technology in EFL online } \\
\text { education raises students' academic } \\
\text { achievement. }\end{array}$ & 73 & 2.76 & 1.073 & Medium \\
\hline $\begin{array}{l}\text { Because of concerns like as cheating or } \\
\text { impersonation, the use of technology in EFL } \\
\text { online instruction does not accurately reflect } \\
\text { students' actual academic achievement. }\end{array}$ & 73 & 3.54 & 1.093 & High \\
\hline
\end{tabular}


Teachers' perceptions of challenges in online learning: Voices from secondary...

\begin{tabular}{|c|c|c|c|c|}
\hline Statement & $\mathbf{N}$ & Mean & $\begin{array}{c}\text { Standard } \\
\text { Deviation }\end{array}$ & Level \\
\hline $\begin{array}{l}\text { The use of technology in EFL online instruction } \\
\text { limits the methods available for assessing } \\
\text { students' performance. }\end{array}$ & 73 & 3.34 & 1.070 & Medium \\
\hline $\begin{array}{l}\text { In EFL online learning systems, objective } \\
\text { questions are preferred for assessing students. }\end{array}$ & 73 & 3.63 & .905 & High \\
\hline $\begin{array}{l}\text { In online learning platforms, it may be difficult } \\
\text { to keep track of students' progress. }\end{array}$ & 73 & 3.45 & .986 & High \\
\hline $\begin{array}{l}\text { In EFL online teaching platforms, it is very } \\
\text { difficult to keep up with grading students' } \\
\text { assignments and assessments. }\end{array}$ & 73 & 3.24 & 1.077 & Medium \\
\hline $\begin{array}{l}\text { Students' lack of technological skills makes } \\
\text { responding to tasks in EFL online teaching } \\
\text { platforms more difficult. }\end{array}$ & 73 & 3.97 & .816 & High \\
\hline $\begin{array}{l}\text { To assess students on EFL online teaching } \\
\text { platforms, I can utilize a variety of assessment } \\
\text { methods such as tests, quizzes, and } \\
\text { assignments. }\end{array}$ & 73 & 2.06 & 1.031 & Low \\
\hline $\begin{array}{l}\text { EFL online teaching platforms provide better } \\
\text { assessment tools than traditional EFL } \\
\text { classrooms. }\end{array}$ & 73 & 2.26 & .928 & Low \\
\hline
\end{tabular}

Table 5 illustrates that the major assessment challenge for EFL teachers was students' lack of technological competency, which makes it more difficult for teachers to respond to assignments in EFL online teaching platforms $(\mathrm{M}=3.97$, $\mathrm{SD}=.816)$. The utilization of objective questions $(\mathrm{M}=3.63, \mathrm{SD}=.905)$, students' real academic achievement $(M=3.54, S D=1.093)$, and the difficulty in following students' progress $(\mathrm{M}=3.45, \mathrm{SD}=.986)$ are other high-ranking problems. Teachers, on the other hand, reported that tests, quizzes, and assignments were effective in assessing students $(M=2.06, S D=1.031)$. Table 6 demonstrates that EFL teachers consider working with students online to be a medium challenge.

Table 6. Challenges with Students in Online EFL Instruction

\begin{tabular}{lllll}
\hline \multicolumn{1}{c}{ Statement } & $\mathbf{N}$ & Mean & $\begin{array}{c}\text { Standard } \\
\text { Deviation }\end{array}$ & Level \\
\hline Overall & 3.13 & & Medium \\
\hline $\begin{array}{l}\text { Because of the integrating technology in EFL } \\
\text { online instruction, students ignore important } \\
\text { learning resources such as hardcover books. }\end{array}$ & 3.16 & .943 & Medium \\
$\begin{array}{l}\text { The integration of technology in EFL online } \\
\text { teaching aids in accommodating students' }\end{array}$ & 2.63 & 1.034 & Medium \\
$\begin{array}{l}\text { individual learning methods. } \\
\text { The integrating technology in EFL online } \\
\text { education motivates students to become more } \\
\text { involved in learning activities. }\end{array}$ & 2.79 & 1.129 & Medium
\end{tabular}




\begin{tabular}{llllll}
\hline \multicolumn{1}{c}{ Statement } & N & Mean & $\begin{array}{l}\text { Standard } \\
\text { Deviation }\end{array}$ & Level \\
\hline $\begin{array}{l}\text { The integrating technology in EFL online } \\
\text { instruction fosters the development of students' } \\
\text { interpersonal skills. }\end{array}$ & 2.75 & 1.102 & Medium \\
$\begin{array}{l}\text { The integrating technology in EFL online } \\
\text { instruction raises the level of stress and anxiety }\end{array}$ & 3.38 & 1.008 & Medium \\
among students. \\
$\begin{array}{l}\text { Students experience a strong feeling of isolation } \\
\text { when using online education platforms, which }\end{array}$ & 3.53 & 1.001 & High \\
may reduce their willingness to study. \\
$\begin{array}{l}\text { In EFL online teaching platforms, students are } \\
\text { more passive observers. }\end{array}$ & 3.38 & 1.150 & Medium \\
$\begin{array}{l}\text { Students cannot use their new information to } \\
\text { draw connections with previous material or } \\
\text { real-world examples in EFL online teaching } \\
\text { platforms. }\end{array}$ & 3.12 & 1.040 & Medium \\
$\begin{array}{l}\text { Work done asynchronously in EFL online } \\
\text { teaching platforms causes students to feel } \\
\text { disconnected from their teacher. }\end{array}$ & 3.21 & 1.083 & Medium \\
$\begin{array}{l}\text { Students' physical absence reduces the } \\
\text { possibility of collaboration in online learning } \\
\text { platforms. }\end{array}$ & 3.36 & .964 & Medium \\
\hline
\end{tabular}

Table 6 reveals that the highest-rated challenges when dealing with students online was a strong sense of isolation perceived by the students, which may reduce their motivation to learn $(\mathrm{M}=3.53, \mathrm{SD}=1.001)$. Other issues are the increasing of anxiety $(\mathrm{M}=3.38, \mathrm{SD}=1.008)$, passive observer $(\mathrm{M}=3.38$, $\mathrm{SD}=1.150)$, less collaboration $(\mathrm{M}=3.36, \mathrm{SD}=.964)$, and students not using hardcopy resources $(\mathrm{M}=3.16, \mathrm{SD}=.943)$. However, the lowest challenges, according to teachers, are promoting the development of students' interpersonal skills through technological integration in EFL online education $(\mathrm{M}=2.75, \mathrm{SD}=1.102)$.

\section{DISCUSSION}

This study looked at how secondary EFL teachers perceived the challenges of online learning in four areas: technology, instruction, assessment, and students. The findings highlight some important points worth discussing. Secondary EFL teachers in this study indicated medium-level challenges in teaching EFL online in terms of technology use, instruction, assessment, and dealing with students, whilst challenges in assessing the students in online learning were considered the highest aspects $(M=3.14)$.

As stated earlier, this study reveals that the top online learning challenge perceived by secondary teachers was the assessment domain. The main assessment difficulty for EFL teachers was students' lack of technological competency, which makes responding to assignments in EFL 
Teachers' perceptions of challenges in online learning: Voices from secondary...

online teaching platforms more challenging for teachers. This finding was in accordance with Abduh, (2021) who discovered that technical issues experienced by students were one of the main challenges faced by teachers while assessing students online. Although Abduh's study focused on university teachers, the findings are consistent with those of our study, which demonstrated that assessing pupils online was difficult for both middle school and university teachers. Other significant issues in this present study include the use of objective questions, students' actual academic achievement, and the difficulties in following students' progress. This agreed with previous studies conducted by Alhuwaydi (2021) and Kitishat et al., (2020) who found that assessing students' actual academic attainment, performance, subjective questions, tracking progress, and responding to assignments were all key issues in online education. Khatoony \& Nezhadmehr (2020) have a different perspective on the challenges in examining students' actual performance in online assessments. He discovered that integrating technology into the classroom can help students demonstrate their real performance during the Coronavirus outbreak. This discrepancy could be due to the students' capacity to use technology prior to the pandemic, allowing teachers to see that their students were able to follow the online classes well. Naturally, this is not the case for students in developing countries, as was the case in our study.

The second most frequently mentioned issue when dealing with students online was a strong sense of isolation felt by the students, which may impair their enthusiasm to learn. This finding is consistent with the findings of Gulnaz et al., (2019), who found that students experience social isolation and boredom while learning remotely. This could be owing to a lack of physical interaction, which is typical of face-to-face learning. Also, although students are accustomed to living alongside their devices, this study discovered that online learning, in which all learning and teaching procedures are carried out online, actually increases students' feelings of anxiety and stress. This is conceivable because students are not used to using their devices to enhance learning activities. They only use their smartphones for communication and entertainment. Goertler (2011) advised analyzing students' language development and digital literacy before class begins to help teachers evaluate the kinds of assistance that students need to be successful in online learning in an attempt to lessen the anxiety associated with technical aspects of language learning. Other concerns discovered here include students becoming less engaged in the teaching and learning process, as well as students' physical absence reducing the possibilities of collaboration. This finding was partially in line with Alhuwaydi's (2021) recent work which reported students were demotivated as a result of a lack of support and harmful learning settings, as well as their passiveness, disengagement, and lack of teamwork. This, however, contradicts the 
findings of Halim \& Sunarti's (2021) study, which discovered that the learning process may be done collaboratively via a number of online platforms. As a result, success in online learning cannot be dissociated from the teacher's ability to provide material and pedagogical approaches which are critical.

The third issue discovered here concerned the difficulties of instruction in online learning. When compared to a face-to-face classroom, EFL secondary teachers thought that fully utilizing technology requires more time to design the learning activities. This could be due to teachers' inefficiency in using technology, which causes them to be delayed in producing lesson materials. This agreed with Mahmoudzadeh's (2014) work who stated that conducting and designing the materials for online teaching is very time-consuming and even hard for teachers. This stance may be supported by a lack of training in Internet and communication information, which may result in teachers becoming unprepared to deliver and design the lessons. Nugroho \& Mutiaraningrum (2020) also found that the lack of success among the participants was strongly connected to their absence of professional abilities in teaching English using digital technology due to a lack of knowledge and training, which is consistent with the findings of this study. Stakeholders must consider suitable and sufficient training for both teachers and students, as well as adjustments to the curriculum.

\section{CONCLUSION}

The findings of this study discovered that among the four domains examined, secondary EFL teachers perceived the challenges in assessing students as the greatest difficulty. The inability of students to employ technology in their learning, student grades that do not reflect their true worth due to cheating issues, and the difficulty of tracking student progress are considered very demanding in online learning and needed a deeper attention. The other three domains, such as technology use, instruction, and dealing with students, revealed medium-level challenges that must be considered in the future in order to attain comprehensive education.

Because face-to-face classrooms will be executed in the coming years due to the controlled spread of covid, now is the moment for policymakers to establish pedagogy and instruction that are appropriate for face-to-face learning. It can therefore be paired with online learning, or blended learning and teachers must be able to design technology-integrated activities that do not negate student needs such as motivation. This study has suggested a number of topics that need to be examined further, notably in terms of students' motivation for taking online classes and the problems they confront while doing so. Further research can be conducted by utilizing qualitative approaches to examine teachers about their perspectives on assessment 
Teachers' perceptions of challenges in online learning: Voices from secondary...

issues, remarkably the use of technology in evaluating students' performance, and how their classroom practice relates to their beliefs.

\section{ACKNOWLEDGEMENTS}

The authors would like to express their gratitude to all junior and senior high school teachers who took the time and effort to participate in this study.

\section{REFERENCES}

Abduh, M. Y. M. (2021). Full-time online assessment during COVID -19 lockdown: EFL teachers' perceptions. Asian EFL Journal, 28(11).

Alhuwaydi, A. A. (2021). Teachers' Perceptions of Challenges in Online Teaching: A Survey Across Universities in KSA. TESOL International Journal, 16(3.1).

Atmojo, A. E. P., \& Nugroho, A. (2020). EFL Classes Must Go Online! Teaching Activities and Challenges during COVID-19 Pandemic in Indonesia. Register Journal, 13(1). https:/ / doi.org/10.18326/rgt.v13i1.4976

Bao, W. (2020). COVID -19 and online teaching in higher education: A case study of Peking University . Human Behavior and Emerging Technologies, 2(2). https://doi.org/10.1002/hbe2.191

Fraenkel, J. R., Wallen, N. E., \& Hyun, H. H. (2017). How to design and evaluate research in education. McGrawHill, 91.

Gao, L. X., \& Zhang, L. J. (2020). Teacher Learning in Difficult Times: Examining Foreign Language Teachers' Cognitions About Online Teaching to Tide Over COVID-19. Frontiers in Psychology, 11. https://doi.org/10.3389/fpsyg.2020.549653

Goertler, S. (2011). Blended and open/online learning: Adapting to a changing world of foreign language teaching. In Present and future promises of CALL: From theory and research to new directions in language teaching.

Gulnaz, F., Althomali, A. D. A., \& Alzeer, D. H. (2019). An Investigation of the Perceptions and Experiences of the EFL Teachers and Learners About the Effectiveness of Blended Learning at Taif University. International Journal of English Linguistics, 10(1). https://doi.org/10.5539/ijel.v10n1p329

Halim, a., \&Sunarti, s. (2021). Online instructional strategies for english language learning during covid-19 pandemic: a case from a creative teacher. joall (journal of applied linguistics and literature), 6(1). https:/ / doi.org/10.33369/joall.v6i1.12452

Hashemi, A. (2021). Online teaching experiences in higher education institutions of Afghanistan during the COVID-19 outbreak: Challenges and opportunities. Cogent Arts and Humanities, 8(1). 
https://doi.org/10.1080/23311983.2021.1947008

Jena, P. K. (2020). Online Learning During Lockdown Period For Covid-19 In India. International Journal of Multidisciplinary Educational Research (IJMER). https://doi.org/10.31235/osf.io/qu38b

Khatoony, S., \& Nezhadmehr, M. (2020). EFL teachers' challenges in integration of technology for online classrooms during Coronavirus (COVID-19) pandemic in Iran. AJELP: Asian Journal of English Language and Pedagogy, 8(2).

Kitishat, A. R., Al Omar, K. H., \& Al Momani, M. A. K. (2020). The Covid-19 crisis and distance learning: E-teaching of language between reality and challenges. Asian ESP Journal, 16(51).

König, J., Jäger-Biela, D. J., \& Glutsch, N. (2020). Adapting to online teaching during COVID-19 school closure: teacher education and teacher competence effects among early career teachers in Germany. European Journal of Teacher Education, 43(4). https://doi.org/10.1080/02619768.2020.1809650

Mahmoudzadeh, S. (2014). The Effect of Using PowerPoint on Iranian EFL Learners' Knowledge of Abstract Vocabulary. Procedia - Social and Behavioral Sciences, 98. https://doi.org/10.1016/j.sbspro.2014.03.519

Mailizar, Almanthari, A., Maulina, S., \& Bruce, S. (2020). Secondary school mathematics teachers' views on e-learning implementation barriers during the COVID-19 pandemic: The case of Indonesia. Eurasia Journal of Mathematics, Science and Technology Education, 16(7). https://doi.org/10.29333/EJMSTE/8240

Mishra, L., Gupta, T., \& Shree, A. (2020). Online teaching-learning in higher education during lockdown period of COVID-19 pandemic. International Journal of Educational Research Open, 1. https://doi.org/10.1016/j.ijedro.2020.100012

Mseleku, Z. (2020). A Literature Review of E-Learning and E-Teaching in the Era of Covid-19 Pandemic. International Journal of Innovative Science and Research Technology, 5(10).

Naylor, D., \& Nyanjom, J. (2021). Educators' emotions involved in the transition to online teaching in higher education. Higher Education Research and Development, 40(6). https:// doi.org/10.1080/07294360.2020.1811645

Nugroho, A., \& Mutiaraningrum, I. (2020). EFL teachers' beliefs and practices about digital learning of English. EduLite: Journal of English Education, Literature and Culture, 5(2). https://doi.org/10.30659/e.5.2.304-321

Zaharah, Z., Kirilova, G. I., \& Windarti, A. (2020). Impact of Corona Virus Outbreak Towards Teaching and Learning Activities in Indonesia. SALAM: Jurnal Sosial Dan Budaya Syar-I, 7(3). 
Teachers' perceptions of challenges in online learning: Voices from secondary...

https://doi.org/10.15408/sjsbs.v7i3.15104

\section{THE AUTHORS}

Dwi Bayu Saputra is an English teacher who graduated from the Indonesian University of Education with a master's degree in 2018. So far, he's written some articles about teachers' reflections, as well as the relationship between their learning practices and their beliefs. He also investigates the challenges that arise in online learning, notably in secondary teachers' viewpoints.

Honesty Yonanda Ayudhia got her master degree in English Education from Indonesia University of Education. She does research in English Language Teaching, mostly in teaching writing skills and writing assessment. Her recent publications are about the quality of writing assessment and also about students' writing performance and strategies relating to the types of Writing Anxiety.

Reci Muswari has been an English teacher for almost ten years. He teaches at the high school level, where he has taught both English and Indonesian. He got his Bachelor degree from Bengkulu Muhammadiyah University and the moment, he is teaching in SMAN 10 Kota Bengkulu.

\section{Appendix}

Questionnaire items

\section{Challenges with using technology in online EFL instruction}

\footnotetext{
Statement

In terms of resources, time, and effort, integrating technology into EFL online teaching is costly.

Due to a lack of proper teacher training, technology integration in EFL online instruction is ineffective.

I am skilled at teaching EFL online using computers.

I can design EFL lessons with the help of computers to deliver online lectures.

To teach EFL online, I have good Internet connectivity and computers.

It is costly to have a computer and Internet connectivity to teach EFL online.

The EFL learning process would be limited by the lack of training in the use of online teaching tools.

In EFL online teaching platforms, poor Internet and device compatibility, such as computers, are challenges.

During live online teaching, I can share screens, applications, and files such as.pdf,.ppt, and.jpg with my students.

I can use microphone, camera, chat, whiteboard, groups, and polls, among other elements of live teaching.
} 


\section{Challenges with online EFL instruction}

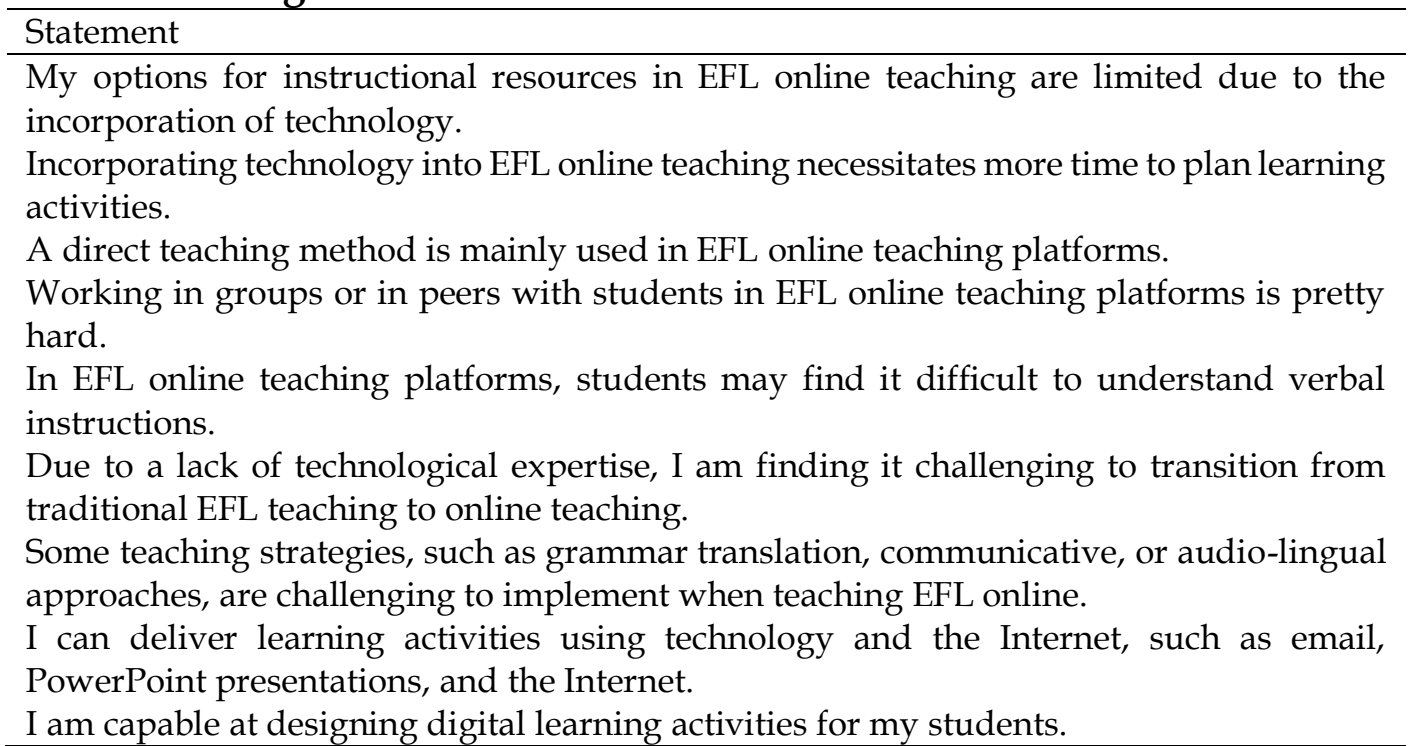

\section{Challenges with assessment in online EFL instruction}

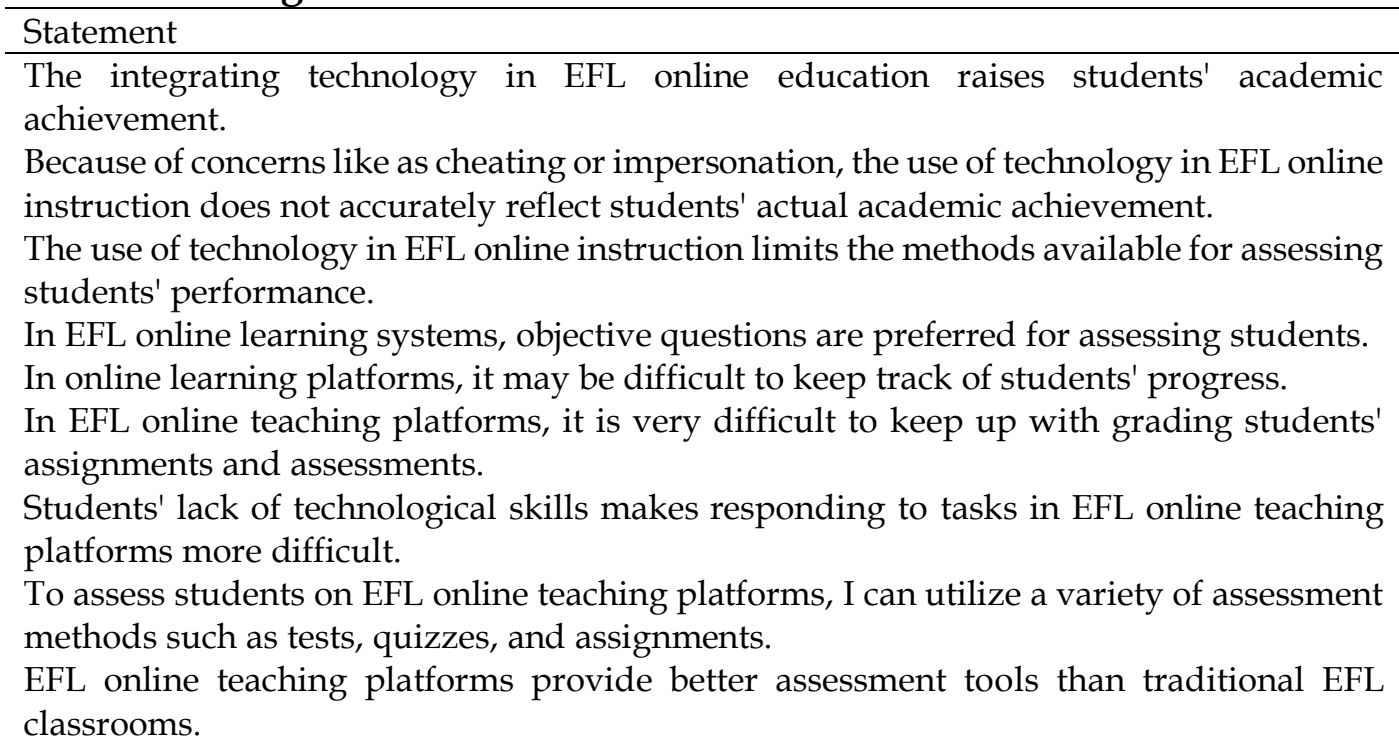

\section{Challenges with students in online EFL instruction}

\footnotetext{
Statement

Because of the integrating technology in EFL online instruction, students ignore important learning resources such as hardcover books.

The integration of technology in EFL online teaching aids in accommodating students' individual learning methods.

The integrating technology in EFL online education motivates students to become more involved in learning activities.

The integrating technology in EFL online instruction fosters the development of students' interpersonal skills.
} 
Teachers' perceptions of challenges in online learning: Voices from secondary...

The integrating technology in EFL online instruction raises the level of stress and anxiety among students.

Students experience a strong feeling of isolation when using online education platforms, which may reduce their willingness to study.

In EFL online teaching platforms, students are more passive observers.

Students cannot use their new information to draw connections with previous material or real-world examples in EFL online teaching platforms.

Work done asynchronously in EFL online teaching platforms causes students to feel disconnected from their teacher.

Students' physical absence reduces the possibility of collaboration in online learning platforms. 